\title{
A TÉRSZERKEZET FOGALMA, ÉRTELMEZÉSE
}

\author{
(The Concept and the Explanation of the Spatial Structure)
}

\author{
SZABÓ PÁL
}

Kulcsszavak:

térszerkezet területi szerkezet regionális tudomány

A térszerkezet a hazai terïleti kutatások és területpolitika egvik kulcsfogalma, ám értelmezése elég sokféle. Emiatt számtalan tudományos elemzés, de több hivatalos dokumentum is eltérö tartalommal használja a kifejezést. Ez a tanulmány arra keresi a választ, hogyan értelmezhetó a térszerkezet fogalma regionális tudományi szempontból.

\section{Bevezetés}

Minden tudománynak, tudományterületeknek megvan a saját nyelvezete, szakszókincse, de míg a természettudományok esetében gyakoribb az átfedés, sürübben találkozunk konszenzuson alapuló fogalom-meghatározásokkal, addig a társadalomtudományoknál még az egy-egy szakterület múvelói is másképp értelmezhetik az egyes kifejezéseket. Igaz ez a térhez köthető fogalmak esetében is. Mivel osztjuk azt a véleményt, hogy a regionális tudomány a társadalmi tértudományok alapvetó közös fogalmait, elméleteit, módszereit egységes rendszerbe foglaló és a társadalmi jelenségeket és folyamatokat ezek felhasználásával vizsgáló társadalomtudomány (Nemes Nagy 1998; Horváth 1999), így egyik hivatásának tekintjük a térhez kapcsolódó kifejezések vizsgálatát és különbözỏ szakterületi szempontból történỏ öszszevetését. A regionális tudományi fogalmakat a társadalomtudományok közös, a társadalmi térhez kapcsolódó fogalmaiként elhelyezve a diszciplína szótárának megalkotása nehéz feladat. Ennek oka, hogy a regionális tudomány, mint gyưjtốhely funkcionál (Benko [1999] szerint e diszciplína a térrel foglalkozó társadalomtudományok metszetében jött létre), így a „regionalisták” különböző tudományos alapokról indulva eltérố gyökerü meghatározásokkal lépnek a színre. S így bár felmerül, hogy a regionális tudomány transzdiszciplináris tudáskészlet (Enyedi 2002), ám a kommunikációhiány és a térelméleti alapok gyengesége alapvetô társadalmi térkategóriáknál az egyes szakterületeknek egymással lényegében semmiféle kapcsolatban nem lévő, élesen elütő tartalmú, ugyanakkor a kizárólagosságra is igényt tartó meghatározásaihoz vezet (Nemes Nagy 1998). Milyen lehetne így a - több szakterület nómenklatúrájára épító - regionális tudományi szótár? Egyes kifejezéseknél biztosan nem lehet egyetlen definíciót adni, hanem alternatív meghatározásokat kell felsorakoztatni. Más esetekben viszont megkísérelhetó a szintézis, ám itt is tehetö egy megkülönböztetés az alapján, hogy szummatív vagy funkcionális fogalmakról beszélünk; azaz a különbözỏ tudományterületek meghatározásainak 
bizonyos szempontok szerinti „összeadásáról” van szó (egy definícióba préselésük), vagy pedig létrehozható ezekből egy olyan értelmezése a fogalomnak, amely egyedi, és így talán regionális tudományi. (Regionális tudományi szótár alkotására hazai kísérletet jelentett a Regionális Tudományi Tanulmányok 11. kötetének appendixe [Regionális tudományi kislexikon].)

E problémákkal a térszerkezet kifejezés kapcsán, annak értelmezésekor is szembesülünk. A térszerkezet a hazai területi kutatások egyik kulcsfogalma, úton-útfélen találkozunk vele, ám értelmezése hiányos, használata pedig nem mindig helyénvaló. A területpolitikát nézve sem jobb a helyzet: a hazai területfejlesztési jogszabályoknak (és fejlesztési dokumentumoknak) immár visszatérỏ eleme a fogalom, de definiálása a legutóbbi időkig elmaradt. Márpedig, ha például országos célként rögzítésre kerül a „harmonikus térszerkezet elérése” egy hatályos törvény alapján, akkor tudnunk kellene mit is jelent, hiszen e nélkül csak homályos jövőkép marad a kitüzött cél. Ráadásul van két, országos hatáskörü, hivatalosan elfogadott tervdokumentum, az (első és második) Országos Területfejlesztési Koncepció és az Országos Területrendezési Terv, amelyek a térszerkezet fogalmát használják, ám a két dokumentum bár kidolgozásuk egy szervezet (egy kormányzati háttérintézmény két részlegének) keretein belül történt - eltérő szemléletben használja a kifejezést, más a két mủ (és alkotói) térszerkezet-felfogása, térszemlélete. Ez a tudományban akár természetes is lehet, ellenben a területpolitikában hatékonyságcsökkenéshez vezethet. Ebben a tanulmányban arra keressük a választ, hogyan értelmezhetỏ a térszerkezet fogalma regionális tudományi szempontból. Ezen belül elötérbe helyeztük a földrajzi (külső) térszerkezet értelmezését. Hasonló, regionális tudományi szempontú fogalomértelmezési kísérletekre egyelöre kevés példa található; ilyen több fogalom esetében Nemes Nagy 1998; Benedek 2000, vagy például az információs társadalomról és gazdaságról Jakobi 2004, a klaszter fogalmáról Patik 2005, a régió fogalmáról Szabó 2005, a struktúravizsgálatról Czirfusz 2007. Több példa található viszont a földrajzi térhez kapcsolódó jelenségek értelmezésére; talán a legtöbbet firtatott esete a határ fogalma.

Fontos kiemelni, hogy a térszerkezet esetében nem áll rendelkezésre sokféle meghatározás, elméleti közelítés (szemben például a régióval [ezekröl ld. Szabó 2005]), így ezek áttekintésén túl a felettébb gyakori használat ad még támpontokat a fogalommagyarázathoz. E miatt előbb vesszük számba a térszerkezet típusait, jellemzöit, majd ezek tükrében próbáljuk meghatározni a jelentését. A tanulmányban csak a fogalom magyar nyelvủ értelmezésére teszünk kísérletet, melynek oka, hogy a térszerkezet idegen nyelvi megfelelői attól függenek, hogy milyen tartalommal töltjük meg a kifejezést. (Így jöhet szóba angol nyelven a spatial structure fogalma, valamint a geographical pattern, spatial pattern; német nyelven pedig a Raumstruktur, Raumordnung fogalmak.) 


\section{A különbözö tudományterületek térszerkezet felfogásai}

A térszerkezet fogalma a köznyelvben nem használatos, mint kifejezés (szócikk) az általános enciklopédiákban, lexikonokban, értelmező szótárakban nem található. A fogalom kötỏdik bizonyos tudományterületekhez (és politikákhoz). E téren viszont abból kell kiindulni, hogy egy összetett kifejezéssel állunk szemben, amely két tagból áll: tér és szerkezet.

A tér, mint fogalom esetében az általános értelmezés rendkívül gazdag, s már a szükebb szakma több müvében is megjelenik (például Korompai 1995; Nemes Nagy 1998; Benedek 2000; Mészáros 2000; Dusek 2004), ezért ezt mellözzük, akárcsak több más tudományterület térértelmezését. A szerkezet fogalma viszont kevésbé tisztázott, ráadásul alapjaiban határozza meg a térszerkezet fogalmát, így erre ki kell térni.

A különböző közismereti mủvek áttanulmányozása alapján megállapítható, hogy a szerkezet fogalma kapcsán egy alapvetö kettősség létezik: a szerkezet több részböl áll, részek összessége, illetve a szerkezet az alkotórészek közötti összefüggés rendje, módja. (E különbségtétel mentén különböző szinonimák a jellemzök: felépítés, alkat, belső forma, belsỏ rend.) Az egyes mủvek szemléletei abban térnek el, hogy melyik részre helyezik a hangsúlyt, illetve esetenként mindkettő megfogalmazást tartalmazzák. Azonban az értelmezéseket inkább a struktúra címszó alatt leljük fel. (A két kifejezés - szerkezet és struktúra - viszonya nem egyértelmú: a szerkezet hivatalos szinonimájaként is tekinthetünk a struktúra fogalmára [Magyar Értelmezö... 1972, 1226], amelyet több lexikon is alkalmaz [akár szinonimaként, akár egymás magyarázatában szerepelnek], ugyanakkor például Zoltán [1984] alaposan kitárgyalja a struktúra és a szerkezet fogalmak közötti különbségeket.)

A különbözỏ enciklopédiák leírásainak szintéziseként a struktúra fogalma így foglalható össze (szummatív fogalomként): elemekböl (részek, alkotóelemek, alkotórészek) áll, mely elemek különbözỏ elrendezödést mutathatnak, rendezettségük van és az elemek egymással különbözö módon összefüggnek, kapcsolódnak (mely akár leírható). Mindezek (elem, helyzet, kapcsolódás) összessége egy egészt, egységet, együttest, rendszert ad, mely valamiként funkcionál, funkciója van. Ez az együttes több mint a részek puszta összessége (több mint összetétel, váz); mint egész önmagában is értelmezhetö, tulajdonságai (természete, jellege) van.

Bár számos diszciplína kapcsolódik a térhez, ám a térszerkezet, vagy annak valamilyen szinonimája, formája szükebb körben jelenik csak meg. A figyelmet a társadalomföldrajzi térhez kötődő tudományágak fogalomhasználatára fordítjuk, így csak rövid kitéröt teszünk az ezen kívül eső körre, a térszerkezet-szemléletet kutatva. A térszerkezet fogalmának leggyakoribb használója a kémia. A kifejezés alatt egy molekulán belül az atomok, ill. atomcsoportok egymáshoz való viszonyát értik. A kémián belül a sztereokémia szakág foglalkozik a térszerkezettel, és e téren számos kapcsolódó fogalom és definíció van jelen: konstitúció, konfiguráció és konformáció (Villányi 1995); a kémia esetében a térszerkezetnél a térbeli elrendezódésen van a hangsúly. Más természettudományok esetében is felbukkan a térszerkezet kifejezés, például a biológiánál (a kémiához való kötődése révén, valamint például: ,struktúra: 
... a növényzet térbeli szerkezete, a növényi populációk - mint struktúra alkotó egységek - elrendezödése." [Biológiai Lexikon 1978, 85]). Nyomokban megjelenik a térszerkezet kifejezés a csillagászatban és a földtudományban is: mindkettő esetében az előzőhöz hasonlóan a szerkezet térbeli formájának (elrendeződés) nyomatékosítása miatt. A bölcsészettudomány köreiben egy-egy szellemi alkotás esetében beszélnek szerkezetről: a mü elemeinek elrendezödéséböl, összefüggéseiböl, arányaiból adódó belső rend, felépítés. Ennek kapcsán az irodalom és a zene mellett a képzömüvészet és müvészettörténet is elötérbe kerül, valamint ennek kapcsán a kompozíció fogalma: a müalkotás felépitése, térszerkezete. Ez utóbbi szemléletek rendre „a térszerkezet: az elemek elrendeződése” felfogást mutatják. A müszaki tudományok esetében a kifejezés „leszükül” a szerkezetre, és e körben a fogalom tág értelmezése a szokványos: a szerkezet az (alkat)részek összessége és ezek elhelyezkedése. Az épitészet is a térszerkezet fogalmának „használója”, leginkább a településtervezés és az épületek belső terei kapcsán találkozhatunk a kifejezéssel, szintén elemek együttesére s egymáshoz való viszonyára utalva.

A társadalomtudományok esetében a társadalmi térhez kötődően a térszerkezet fogalma sokféle értelemben jelenik meg. Ennek egyik oka, hogy a társadalmigazdasági térrel kapcsolatos felfogások mind a különböző tudományágak között, mind az egyes tudományágakon belül nagyfokú polarizáltságot mutatnak (Horváth 1989), így a társadalmi térnek sok fajtája van, melyek különböző módon osztályozhatók, rendszerezhetők. Ezek közül a térszerkezet gondolatkörhöz erösen kötődik azon felosztás, hogy az objektív (reális) tér felbontható a társadalom földi térhez kötött, lokalizált külső terére és az egyes társadalmi szférák belső terére (Nemes Nagy 1998); a társadalmi teret a társadalom külső és belső terei együtt alkotják. Ezt a kettősséget Horváth (1989) gazdasági viszonylatban értelmezi: létezik az absztrakt gazdasági tér (az adott társadalmi-gazdasági struktúrában elhelyezkedő, földrajzi rendszerektől független, ezáltal területi kategóriákkal nem jellemezhetö gazdasági viszonyok halmaza) és a konkrét gazdasági tér (a földrajzi térben elkülönülö objektumok közötti kapcsolatokat hordozó gazdasági térforma). Hasonlóan konkrét és absztrakt tereket különböztet meg Ashworth-Bora (1999), valamint Faragó (2005) is.

Kérdésként merül fel, hogy mindkettö esetében beszélhetünk-e térszerkezetről? Igen, mivel a térszerkezet általános érvényü, s így mind a földi térben egyértelmủen lokalizált, mind a földi lokalizációtól független, térjellemzöket felmutató rendszerekben fellelhetö. A térhez itt a szerkezetet úgy lehet párosítani, hogy a társadalmi térnek a külső térben (a földrajzi térben) értelmezhető szerkezete (a társadalmi tér külső szegmensének szerkezete, a társadalmi tér külső szerkezete) az ủn. külső szerkezet, külsö térszerkezet (földi, fizikai, földrajzi szerkezet, térszerkezet lehet az alternatív elnevezés), a társadalmi térnek a belső térben értelmezhető szerkezete (a társadalmi tér belső szegmensének szerkezete, a társadalmi tér belső szerkezete) pedig az ủn. belső szerkezet, belső térszerkezet. De akkor mit jelent a társadalmi térszerkezet? Ha elfogadjuk a két térértelmezést (külső és belső tér), akkor a társadalmi térszerkezet a kettő szerkezet együtt, tehát a társadalmi térszerkezetet a társadalom külső és belsö térszerkezete együtt alkotja. 
Miként van jelen e dualitás a tudomány hétköznapjaiban? A belső terek kutatásában a szerkezet mellett a térszerkezet fogalom kevésbé használatos, a területi kutatásokban térszerkezeten pedig csak a külső térszerkezetet értik. (Azonban nem szerencsés egy konkrét földrajzi tér belső szerkezetéről beszélni [Magyarország belső térszerkezete], hiszen mit jelent akkor e tér külső szerkezete [Magyarország külső térszerkezete].) Megállapítható utóbbit nézve, hogy a területi kutatások, a külső terek kutatásai nem nagyon kapcsolódnak össze a belső terek kutatásával, így a különböző térszerkezet-kutatások gyakorlatilag földrajzi szerkezet, földrajzi térszerkezet kutatások. Ennek oka, hogy a regionalisták a belsỏ terek elemzését tulajdonképp nem tekintik a saját tudományukhoz tartozónak, de a másik oldal sem jeleskedik e szintézisben: a belső terek kutatói általában megfeledkeznek a területi dimenziókról (Nemes Nagy 1998). Ezek eredményeként a két tér (belső és külső) és a komplex térszerkezet egyidejú kutatása nagyon ritka. (Ezért számítanak üdító kivételnek, ha a klasszikus társadalomtudományok és a földrajzi térrel foglalkozó diszciplínák közötti kapcsolati szálak kiépülnek, s így egymás „tereit” figyelembevevő, sỏt kombináló kutatások alakulnak ki, valamint elméleti kérdéseknél, leírásoknál az összetett szemlélet jelenik meg [pl. Strassoldo 1990; Böhm 1996].) A térszerkezet fogalmát használó számos, a földrajzi tér vizsgálatához kötődő munka áttanulmányozása alapján részben igazolva látjuk Fodor (1985) véleményét, miszerint a földrajz a fizikai térben lokalizálja a társadalmi jelenségeket, illetőleg a különbözö társadalmi jelenségeknek a fizikai térben történő fizikai terjedését elemzi, ezáltal a hely és helyzet-meghatározás nem a társadalmi térben, hanem a fizikai térben történik, $s$ így a földrajz valójában a társadalmi térszerkezet helyett annak területi vetületét elemzi. Ezt úgy finomítanánk, hogy a földrajz a társadalmi térszerkezet egyik szegmensét, a területi vonatkozását elemzi (azaz a külső társadalmi térszerkezetet, avagy más néven a földrajzi térszerkezetet). Ez, úgy gondoljuk, az egyik leglényegesebb elem e kérdéskörben. Ezzel egyúttal el is jutunk egy ủjabb fontos különbségtételhez: tér- és/vagy területi szerkezet.

Egyetértünk Nemes Nagy (1998) azon véleményével, hogy a - hétköznapi szóhasználattal ellentétben - a társadalomtudományokban indokolt különbséget tenni a tér és a terület, a térbeli és a területi kifejezések között (elöbbi általánosabb értelmủ, míg utóbbi földrajzi térségekre vonatkozik). Így a földrajzi térszerkezet fogalom helyett talán célszerübb lenne használni a területi szerkezet kifejezést, hiszen közöttük értelmezésbeli különbség van, és a mai területi kutatások túlnyomó többsége gyakorlatilag a területi szerkezet kutatása. De ezek a gondolatok csak akkor helytállók, ha elfogadjuk a belső és külső tér közötti differenciát. Azonban itt szól közbe a hétköznapok valósága, vagyis az, hogy az általános elterjedtségböl kifolyólag a térszerkezet fogalma már nem cserélhetö le a földrajzi terek kutatásai esetén területi szerkezetre, a "szokásjog" erösebbnek bizonyul minden térelméleti okfejtésnél. (E szaknyelvi gondolatkörhöz tartozik, hogy a térszerkezet, a tér szerkezete és a térbeli szerkezet egyaránt értelmezhető, és a mindennapi területkutatás gyakorlata szerint ugyanazt jelentik, valamint az, hogy a szerkezet pedig a struktúra szóval szokott felcserélődni [térstruktúra].) 
Lényeges része e kérdéskörnek, hogy hogyan alakult a két fogalom (térszerkezet, területi szerkezet) hazai használatának életútja. Az 1970-es, 1980-as évek szakirodalmában alig-alig bukkan fel a térszerkezet fogalma, viszont a területi szerkezet számos publikációban jelenik meg. Ennek egyik okára Bartke $(2006,3)$ hívja fel a figyelmet: „Az egykori Tervhivatal 1966-ban megalakult Tervgazdasági Intézetének Tervezési Osztálya munkatervében a következő fó kutatási témakört fogalmazta meg: «A gazdaság térszerkezetének sajátosságai, térszerkezeti modellek kidolgozásának módszertani kérdései.» ... A kutatási részeredmények publikálásakor természetesen használták a 'térszerkezet' kifejezést, ... Az 1970-es évek elején bizonyos fordulat történt a kifejezés használatában. Egy szakmai szöveg angolra forditásának ellenőrzésekor azt tapasztalták, hogy a fordító a 'térszerkezetet' 'configuraton'-nak feleltette meg; amelyet ... az atomi, molekuláris stb. térszerkezet értelmében használják. Ettől kezdve a tanulmányokat készítök a térszerkezet kifejezést a 'területi szerkezettel' helyettesítették, mint az előző szinonimáját." Úgy túnik, hogy a területi szerkezet dominanciáját követöen idövel kezdett kiegyenlítödni a két kifejezés használatának aránya. (Ehhez kapcsolódik, hogy van olyan szerzö, aki szinonimaként használta a kettőt, míg más szerzők vagy egyiket, vagy másikat írták le következetesen.) Az elmúlt években azonban a térszerkezet fogalma fokozatosan felülkerekedett, s ma már alig akad szerzö, aki a területi szerkezet kifejezést használná.

\section{A térszerkezet-tipusok}

A konkrét „térszerkezet eseteket” tekintve kétféle csoport alkotható, amelyek a földrajzi térhez szorosan kapcsolódnak: egyik valamely jelenségnek a földrajzi térben való megjelenéséhez kötődik (társadalmi, gazdasági, etnikai stb. térszerkezet), a másik egy-egy földrajzi térség leírásához, amelyen belül a különböző jelenségek együttesen vannak jelen (Európa, Magyarország stb. térszerkezete). Természetesen elöbbi esetében is egy-egy konkrét földrajzi tér az alap, ám ez nem komplex módon jelenik meg, hanem csak egyik kiemelt „layer”-éről van szó.

A kutatók felfogásában számos jelenségnek és területnek van térszerkezete, mint az kiderül a referált földrajzi, regionális tudományi folyóiratokra, szakmai könyvekre támaszkodó gyüjtésünk alapján (1. táblázat). (Itt csak a térszerkezet volt a vizsgált elem, így a térbeli szerkezet, térstruktúra, területi szerkezet stb. a gyüjteményben nem is szerepel.) Úgy tủnik, mintha kissé parttalanná és tisztázatlanná vált volna a fogalomhasználat. Több olyan jelenség is van, amelynél - véleményünk szerint - a térszerkezet kifejezést nem célszerü használni, esetleg a területi szerkezet (indokát ld. korábban) vagy a területi egyenlötlenség, területi különbség fogalmakat (indokát ld. később); emellett több olyan térkategória van, ahol szintén nem igazán értelmezhető vagy felesleges a kifejezés. (E két csoport és az elöbb tárgyalt külső-belső tér kapcsán csak annyit jegyeznénk meg, hogy regionális tudományi körben [!], ha a jelenségek esetében nem a belső, hanem a külső térröl van szó, célszerü lenne a földrajzi jelző beemelése a kifejezésbe [pl. társadalom, gazdaság föld- 
rajzi térszerkezete]; a földrajzi terek esetében viszont ez szükségtelen [pl. Magyarország térszerkezete, hazai térszerkezet], mivel itt a kifejezést mindenki a külsö térre vonatkoztatja.)

\section{TÁBLÁZAT}

A térszerkezet ( ) különbözö jelenségekhez és földrajzi terekhez kapcsolva (The Spatial Structure Connected to Different Objects, Occurents and

Geographical Areas)

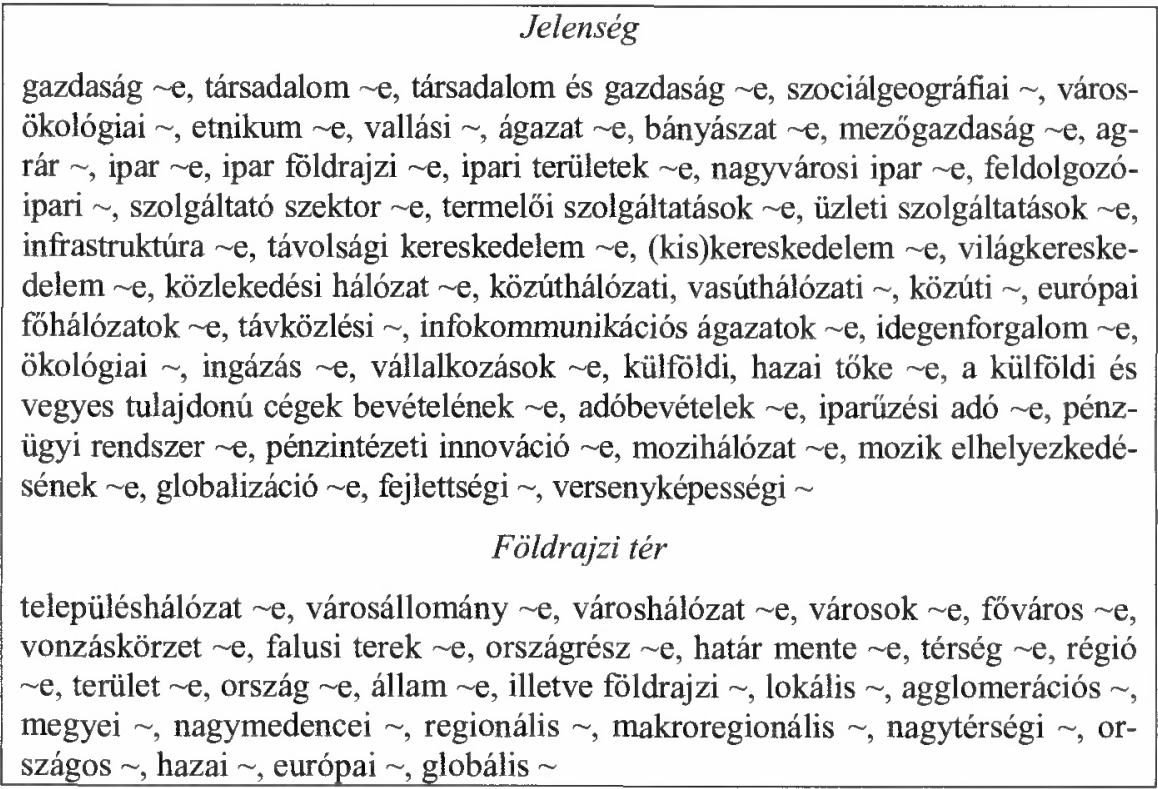

Forrás: Saját szerkesztés.

A jelenségek esetében, a gyakori használat mellett, alig-alig akad érdemi meghatározás az egyes térszerkezet-típusokra (pl. gazdasági térszerkezetre Varga 2005, világgazdasági térszerkezetre Golobics 2002). A térszerkezet különbözó területi szintjeinek azonosításai (pl. Süli-Zakar [1997, 7] Magyarországon hét ún. „„érszerkezeti szintet" különít el: országos, regionális, nagytérségi, kistérségi, települési, lakókörzeti és - a nehezen értelmezhetö - háztartási) szintén gyakorlatilag nem tartalmaznak definíciószerü leírást. A viszonylag kevés értelmezés ellenére rendkívül elterjedt a fogalom használata, amit az előzővel megegyező metóduson alapuló, másik kontextus-gyüjtés is alátámaszt (2. táblázat). E szóösszetételek egy része - véleményünk szerint - itt is értelmezhetetlen, melyeket, ha kizárjuk, akkor is még jó pár marad, amelyekre akár külön szakmai szótárat is lehetne készíteni. Az eddig leírtak ismeretében immár érdemes végiggondolni, hogy mit is jelent a térszerkezet fogalma a regionális tudomány szemszögéból. 


\section{TÁBLÁZAT \\ A térszerkezet ( ) különbözö kontextusokban \\ (The Spatial Structure in Different Contexts)}

\section{Jelzöi}

társadalmi $\sim$, gazdasági $\sim$, társadalmi, gazdasági $\sim$, urbanizációs $\sim$, rurális $\sim$, szociális $\sim$, harmonikus $\sim$, kiegyensúlyozott(abb) $\sim$, kedvezö(bb) , optimális $\sim$, elméleti $\sim$, racionális $\sim$, funkcionális $\sim$, komplex $\sim$, belső $\sim$, sajátos $\sim$, markáns $\sim$, hagyományos $\sim$, klasszikus $\sim$, önálló $\sim$, dominált $\sim$, megváltozott $\sim$, formálódó $\sim$, kialakult $\sim$, felbomlott , átalakuló $\sim$, problémás $\sim$, kiforratlan $\sim$, visszaszoruló $\sim$, megszünö $\sim$, szabályos $\sim$, tagolt $(a b b) \sim$, képlékeny $\sim$, mozaikos $\sim$, diverzifikált $\sim$, fenntartható $\sim$, tágabb $\sim$, mai $\sim$, meglévő $\sim$, jelenkori $\sim$, korábbi $\sim$, történeti $\sim$, jövőbeli $\sim$, távlati $\sim$, új , épitendö $\sim$, müködö , demokratikusabb , dekoncentrált , centralizált , túlcentralizált $\sim$, övezetes $\sim$, gyürús-öves $\sim$, sugaras $\sim$, monocentrikus , egypólusú , egyközpontú $\sim$, kettősséget mutató , hármas osztatú , kettős, hármas hierarchiaszintú , többpólusú , poszt-szuburbán

\section{Cselekmények}

$\sim$ kialakulása, $\sim$ felépülése, $\sim$ fejlődése, $\sim$ változása, $\sim$ alakulása, $\sim$ átalakulása, $\sim$ átrendeződése, $\sim$ differenciálódása, $\sim$ összekapcsolódása, $\sim$ torzulása, $\sim$ széttöredezése, $\sim$ szétesése, $\sim$ regenerálódása, $\sim$ megmerevedése, $\sim$ alakítása, $\sim$ átalakítása, $\sim$ kialakítása, $\sim$ kiépítése, $\sim$ megteremtése, $\sim$ létrehozása, $\sim$ illesztése, $\sim$ felosztása, $\sim$ felbontása, $\sim$ darabokra bontása, $\sim$ kedvezỏ alakítása, $\sim$ arányos fejlesztése, modernizációja, modernizálása, korszerüsítése, rekonstrukciója, fejlődésének elősegítése, -rendezés, et formál, et átformál, et alakit, 〜et befolyásol, en változtat, et megkettöz, et old, felé való törekvés, kapcsolódás a $\sim$ be, $\sim$ leírása, bemutatása, röl tájékoztatás, vizsgálata, elemzése, $\sim$ kutatása, $\sim$ feltárása, értékelése, $\sim$ ismerete, $\sim$ térképi ábrázolása, arányosabbá válása

\section{Birtokai}

$\sim$ területe, $\sim$ csomópontja, $\sim$ központja, $\sim$ góca, $\sim$ gócterülete, $\sim$ hálózata, $\sim$ tartópillére, $\sim$ alapja, $\sim$ eróvonala, $\sim$ gazdasági erővonala, $\sim$ sávja, $\sim$ váza, $\sim$ állapota, $\sim$ egyensúlya, $\sim$ merevsége, $\sim$ arányai, $\sim$ összetettsége, $\sim$ kapcsolatrendszere, $\sim$ tér és időbeli dinamikája, $\sim$ jelentösége, $\sim$ jellemzöje, $\sim$ jegye, $\sim$ alapvonása, $\sim$ (negatív) vonása, $\sim$ problémái, $\sim$ sajátosságai, $\sim$ erői, $\sim$ kötöttsége, $\sim$ funkciója, átrendeződési irányai, $\sim$ sokszínủsége, $\sim$ megnyilvánulása, $\sim$ logisztikai mozgása

\section{Kapcsolódó egyéb fogalmai}

$\sim \mathrm{i}$ egység, $\sim \mathrm{i}$ elem, $\sim \mathrm{i}$ góc, $\sim \mathrm{i}$ vonal, $\sim \mathrm{i}$ tengely, $\sim \mathrm{i}$ irány, $\sim \mathrm{i}$ váz, $\sim \mathrm{i}$ kép, $\sim \mathrm{i}$ dimenzió, $\sim \mathrm{i}$ tényező, $\sim \mathrm{i}$ kapcsolat, $\sim \mathrm{i}$ kapcsolatrendszer, $\sim \mathrm{i}$ következmény, $\sim \mathrm{i}$ típus, $\sim \mathrm{i}$ modell, $\sim \mathrm{i}$ szint, $\sim \mathrm{i}$ eredet, $\sim$ jellemzö, $\sim$ i jellegzetesség, $\sim$ i hatás, $\sim$ i változás, $\sim$ differenciáltság, $\sim$ i sajátosság, $\sim$ i jelentöség, $\sim \mathrm{i}$ feltétel, $\sim \mathrm{i}$ hely, $\sim \mathrm{i}$ helyzet, $\sim \mathrm{i}$ elhelyezkedés, $\sim \mathrm{i}$ adottság, $\sim \mathrm{i}$ hiányosság, $\sim \mathrm{i}$ válság, $\sim \mathrm{i}$ struktúra, $\sim \mathrm{i}$ rendszer, $\sim \mathrm{i}$ manifesztáció, $\sim \mathrm{i}$ paradoxon, $\sim \mathrm{i}$ forma, $\sim \mathrm{i}$ struktúra, $\sim \mathrm{i}$ változás, $\sim \mathrm{i}$ fejlödés, $\sim$ i mozgás, $\sim \mathrm{i}$ átrendeződés, $\sim \mathrm{i}$ egyenlőtlenség, $\sim$ i eszménykép, $\sim \mathbf{i}$ vázlat, $\sim \mathrm{i}$ elemzés, $\sim \mathrm{i}$ analizis, $\sim \mathrm{i}$ megközelítés, $\sim \mathrm{i}$ gondolkodás, $\sim \mathrm{i}$ konzekvencia, $\sim \mathrm{i}$ javaslat, $\sim \mathrm{i}$ irányelv, $\sim \mathrm{i}$ feladat, $\sim$ i terv, $\sim \mathrm{i}$ tervmúvelet, $\sim \mathrm{i}$ tervlap, $\sim \mathrm{i}$ jövökép, $\sim \mathrm{i}$ koncepció, $\sim \mathrm{i}$ szempont, $\sim \mathrm{i}$ konfliktus, $\sim \mathbf{i}$ probléma, $\sim \mathrm{i}$ feszültség, $\sim \mathrm{i}$ célkitüzések, $\sim \mathrm{i}$ alapú fejlesztés, $\sim \mathbf{i}$ összefüggések, $\sim \mathbf{i}$ elözmények, $\sim \mathrm{i}$ következmény, $\sim \mathrm{i}$ vonatkozások, $\sim \mathrm{i}$ bizonyíték, $\sim \mathrm{i}$ korrekció, $\sim \mathrm{i}$ egységek hierarchiája, $\sim$ i centrum-periféria reláció, központok $\sim$ összekapcsolódása, egységes $\sim$ i rendszerként funkcionál, ország $\sim$ i optimalizálása, komplex $\sim$ i struktúra, tengelyek a $\sim$ ben, változási irányok a ben, innovációs pontok, zónák a ben, szerep a ben, elhelyezkedés a $\sim$ ben, források a ben, terjedés a $\sim$ ben, átmenet a ben, ben elfoglalt hely, ben elfoglalt sajátság, ben egyenlötlenség, ben változás, ben elkülönül, ben csoport, ben müködő forma, ben megnyilvánuló gazdasági egyenlőtlenség, ben zajló koncentrációs folyamat, ileg meghatározó, et alakító jelenség, et alakító innováció, átmenet et újraformálja, átformálni et, optimális re való törekvés, változások átrajzolják ország ét, két illeszkedése, megosztottabbá válik, fejlesztési lehetöség, a makrogazdasági növekedésben játszott szerepe

Forrás: Saját szerkesztés. 


\section{A térszerkezet regionális tudományi meghatározása}

A térszerkezet fogalmának regionális tudományi értelmezése során megállapithatjuk, hogy a különbözö meghatározások a szerkezet-felfogástól függően háromféle kategóriába sorolhatók.

Az első típusba azok tartoznak, amelyek a térszerkezet mindkét jellemzőjére, az elemekre és azok térbeli elrendeződésére is felhívják a figyelmet. Ilyen Nemes Nagy $(1998,40)$ egyenlőtlenség és rendezettség kettőse: „Az egyenlótlenség és a rendezettség adott jellemzői egy-egy alakzatot, konfigurációt határoznak meg. A konfiguráció (jellemzỏen matematikai eszközökkel) leírható. A müködő rendszerek konfigurációja a térszerkezet." Itt arra hívhatjuk fel a figyelmet, hogy a nem társadalomtudományi kör (például a számítástechnika és a kémia) fogalomhasználatában a konfiguráció már egy mủködő rendszer jellemzője. Hasonlóan a kettősség (elhelyezkedés és térkitöltés) jelenik meg Mészárosnál (2000, 25) is: „Felismerték, hogy az elhelyezkedés geometriájának hasznossága nem elvi kérdés, hanem tény, mert az elhelyezkedés geometriája egyben a magyarázat geometriája is. Csak éppen nem geometrikus nyelven kell „elövezetni”! Ezt a bonyolult okoskodást oldotta fel tulajdonképpen a 60 -as években bevezetett új fogalom, a térszerkezet. A térszerkezet valójában állapot, de egyben az a mód is, ahogyan a müködő természeti és társadalmi folyamatok megszervezik, elfoglalják, kitöltik a teret. A fogalom maga annak a kettősségnek a felismeréséből ered, amely megjelenik, kifejeződik a területi (térbeli) folyamat és a térben megjelenö szerkezet között." Lényeges eleme e meghatározásnak, hogy a dinamikára is felhívja a figyelmet a szerző. (Az idő és a térszerkezet öszszekapcsolására e tanulmányban nem térhetünk ki, de a statika-dinamika végiggondolása fontos része a kérdéskörnek.) Szintén e szemléletet képviseli, de a struktúra fogalma kapcsán Köszegfalvi (1985, 33): „A "struktúra» fogalmát úgy értelmezzük, mint ami kifejezésre jutatja a területi társadalmi-gazdasági fejlődés során az egészet ... A struktúra kifejezést ad az illetô egész részeinek ... A struktúra fogalmának ez az értelmezése a részek ... közötti viszonyok megjelölésére is alkalmazható.", illetve a gazdaságra vonatkoztatva Zoltán $(1984,148)$ : „Az erővonalak, erősávok, tengelyek és erőközpontok egyiittesen alkotják a gazdasági élet alapvető makrostruktúráját, térszerkezetét. Ez a makrostruktúra az egyes országokra nagyon jellemző térbeli konfigurációkat (alakzatokat) alkothat. A legtöbb ország gazdaságának térszerkezete néhány ilyen tengelyből, ipari sávból és erővonalból felrajzolható."

A második típus jellemzöje, hogy az alkotóelemekre helyezi a hangsúlyt. Területtervezési-területrendezési gondolatkörből fakad Baráth $(1987,36)$ ilyen jellegủ meghatározása: „A funkcionális fejlettség alapján rangsorolt elemek osztályai alkotják a (hagyományos értelemben is vett) településhálózatot (funkcionális területi szerkezet), míg a müszaki-fizikai tulajdonságok alapján épül fel a müszaki-fizikai szerkezet (müszaki hálózatok által kialakított szerkezet), területfelhasználás. E két szerkezet együtt alkotja az úgynevezett «térszerkezetet»." Hasonlóan az alkotórészekre teszi a hangsúlyt, de tágabb környezetet vesz Krajkó (1989): „A gazdasági térszerkezeten - 
tömören fogalmazva - az egymáshoz szorosan kapcsolódó gazdasági, társadalmi, természeti tényezök, folyamatok térbeli rendszerét értjük."; a térszerkezet elemei esetében a természeti környezet, termelési szféra, népességi szféra, települési szféra. E tág szemlélet jellemzi Benedek (2000, 141) leírását is: „Térstruktúra: a cselekvések eredményeként létrejött anyagi artefaktumok (településszerkezet, területhasznosítás), az ezeket létrehozó társadalmi struktúrák, valamint a természeti erőforrások alkotják. Az első kettőt még elsődleges térstruktúrának is nevezzük. A természetes erőforrásokat még másodlagos térstruktúrának is nevezhetjük. A térstruktúra a tevékenységek, a cselekvés kontextusát alkotja, és mint bizonyos célok elérésére felhasznált eszköz vagy bizonyos célokat meghiúsító akadály kap jelentést." Itt érdekes, de sajátos szemlélet a természeti tényezők másodlagos mivoltának hangsúlyozása. Szintén e típusba sorolható még Bodó $(2005,115)$ - kissé összetett és elemeiben nem tisztázott - meghatározása: „Térszerkezet. Itt a tér területet jelent. A szerkezet pedig társadalmi struktúrákat. A kettő együtt: természeti értékek és térségi terhelhetőség; területhasználat és térségi egységek; infrastruktúra és új funkciók; hagyomány és fejlesztés; értékek és érdekek." Az utóbbi három vélemény - felfogásunkban - inkább a földrajzi környezet (a külső tér) meghatározását jelenti.

A harmadik típus jellemzỏje, hogy a térszerkezet (területi szerkezet) „viszonyítási” részére helyezi a hangsúlyt. Ilyen például Bartke $(1989,9)$ meghatározása: „Területi szerkezeten a gazdaságot, illetve a társadalmat alkotó különféle elemek térbeli megoszlását, egymáshoz viszonyított elhelyezkedését értjük." (Bartke e meghatározása a társadalomföldrajzi környezetre szorítkozik, később viszont a területi szerkezet alkotóelemeinek már a természeti környezetet, valamint a mủvi környezetet, a társadalmat és a gazdaságot tekinti, sőt e szintek kiegészülnek az életmód, az értékrend és az eszmék szintjeivel, s mindezek együttesen építik fel az ún. regionális szerkezeti modellt [Bartke 2001].) (Hasonlóan a térbeli megoszlásra helyezi a hangsúlyt, igaz a gazdaságra szükítve Varga [2005]: a gazdasági térszerkezet a gazdasági tevékenységek térbeli eloszlása [egyenletes, sürúsödés]). A területrendezés esetében - Baráthhal ellentétben - e szemléletet látja Paksy (1997, V): „Szakmánk egyaránt használja a területszerkezet, térszerkezet és területi szerkezet fogalmakat. Úgy tapasztaltam, hogy a szakma mindhárom elnevezés használatánál valamilyen társadalmi, gazdasági vagy környezeti elem térbeli elrendeződésével összefüggő viszonyokat, a településrendezésben térbeli megoszlásának sajátosságait, a térbeli rendjét kívánja kifejezni...” „Rendezettségi” szemléletben fogant Faragó $(2004,10)$ regionális tudományi definíciója is: „A térben egymás mellett létező jelenségek egymáshoz fúződő viszonyaik, kapcsolataik alapján különböző elrendeződéseket (rendezettség), térstruktúrákat alkotnak." A szerző tartózkodik a külső (fizikai, földrajzi) környezet megnevezésétől, sőt térszemléletéból eredően el is szakad ezektől, véleménye szerint ugyanis csak az ember szemszögéböl beszélhetünk térszerkezetröl: a térstruktúrák részben a használatból következő viszonyrendszerből erednek, másrészt a térszemléletünknek megfelelöen alakulnak (Faragó 2005).

A különböző térszerkezet-felfogások azonban más szempont szerint is osztályozhatók: a térszerkezet összetett tartalmához való közelités módja determinálja a 
fogalom értelmezéseit, amelyek a térszerkezet-elemekre és ezek egymáshoz való viszonyára épitve választhatók szét. Ez a gyakorlatban úgy jelentkezik, hogy alapvetően kétféle szemlélet van jelen. Egyrészt van egy (inkább földrajzi, területrendezési, müszaki-fizikai), amely a földrajzi környezet elemeihez, ezen belül vagy a térségekhez, vagy az egész teret lefedö, behálózó településrendszerekhez, közlekedési, infrahálózatokhoz stb., mint térszerkezeti egységekhez kötődik (a térszerkezet térelemekből és a közöttük lévő térkapcsolatokból felépülő, múködő rendszer). A másik (inkább regionalista, területfejlesztési) szemlélet a területi egyenlötlenségek kutatása során, a területegységek közötti mennyiségi és minőségi differenciák fel-tárása révén fogalmazza meg a térszerkezetet.

Az első szemlélet bemutatására több földrajzi munka idézhetö, amelyekben egyrészt funkciók szerint elkülönülő lokális területegységek, vagy az ezekből szervezödỏ regionális hálózatok, másrészt összetett tartalmú térségek jelennek meg mint térszerkezeti elemek.

A térség, mint térszerkezeti egység azonosítása „érhetö tetten" például Mészáros munkájában $(1994,89)$ : „általában egyetértés van abban, hogy a szúkebb értelemben vett vonzáskörzet a város központi funkciói által kialakított térszerkezeti egység”, vagy Györi (1999) esetében, aki szerint a térszerkezeti egységek hierarchiájában a legalacsonyabb fokú térszerkezeti egység a vonzáskörzet. Ennél lejjebb megy Kocsis (1996): a térszerkezet legkisebb elemei szerinte a KSH számlálókörzetek; ugyanakkor a térszerkezeti hierarchia csúcsa érhető utol Probáld $(1995,41)$ tanulmányában: ,a gazdaságföldrajzban az országokon belüli munkamegosztás rendszerének alapvető fontosságú elemei a különböző méretü és rangú térszerkezeti egységek (rajonok) hierarchiájának csúcsán álló komplex (integráns) gazđasági körzetek".

Külön jelenség- és kérdéskör e téren a régió és a térszerkezet kifejezések összekapcsolása. (Nemes Nagy [2003] szerint a regionális tudományi gondolkodásban a régió a térszerkezet fogalmához kötődik, de a különbség a fogalompár tagjai között távolról sem elhanyagolható.) Egyrészt jelen van a régió térszerkezete, például Benedek $(2000,62)$ szerint a régiót az „alkotó térstruktúra egyedisége határozza meg”, illetve Süli-Zakar $(1997,7)$ azt mondja, hogy „a régió: magasan szervezett térstruktúra". Másrészt felmeriil, hogy a régió egyenlö egy térszerkezettel: Frisnyák $(1996,39)$ szerint Magyarországon a nagy térszerkezeti egységek a régiók. Harmadrészt megjelenik az is, hogy a térszerkezet része, eleme a régió: Rechnitzer $(1999,121)$ szerint ,az ország térszerkezetében vannak ... régiók”; Faragó szerint $(2004,11)$ pedig „,a régiók ... a térstruktúra mesterséges, adminisztratív elemei", illetve a régió a tartalom felöl közelíthetö térszerkezeti egység. (Véleménye szerint ,a mikro-, mezo- és makrorégiók ... sajátos térszerkezeti egységek" [Faragó 2004, 12]). Beluszky-Gyóri (2004) szerint is a régió hivatalos térszerkezeti egység lehet. (A hivatalos térszerkezeti egység itt, mint a közigazgatási térszerkezet eleme kerül elö.)

Az első szemlélet két értelmezése együtt van jelen például Tóth munkáiban (Tóth 1993a; 1993b; 1996; Tóth-Pap 2002). Véleménye szerint egyrészt a települési rendszer központi szerepkörü elemeihez idővel egyre nagyobb terek tartoznak, létrejön egy „alapvető térszerkezeti egység”: egy központi szerepkörü település és a hozzá 
kötödö tér egysége, azaz egy központ és vonzáskörzete (Tóth 1993a, 122), mint térség; szerinte Magyarország ilyen (objektíven létezó) térszerkezeti egységekből áll (Tóth 1996). A kutató azonban a másik közelítést is értelmezi, miszerint hazánk térszerkezete elsősorban a közlekedési rendszer konfigurációja alapján vette fel jellegzetességeit, és a térszerkezeti vázra épül a magyar településrendszer konfigurációja (Tóth 1993b), valamint kiemeli, hogy ,a városhálózat a térszerkezet egyik leglényegesebb vázalkotó eleme” (Tóth 1996, 571), sőt azt is megfogalmazza, hogy ,a térszerkezet alapkategóriája a település” (Tóth-Pap 2002, 295). A ,település, mint térszerkezeti egység" szemlélet azonban ritkább a hazai térszerkezeti kutatásokban, aminek okát Beluszky-Győri munkájában $(1999,8)$ lehet talán felfedezni: véleményük szerint a korábban jellemző mozaikos térszerkezet átalakult, a települések közötti differenciák mérséklödtek, és a régiók között kialakuló különbségek lettek a meghatározók.

A településrendszer mellett a közlekedés is fontos eleme a térszerkezetszemléleteknek: például Tóth (1996) szerint a közlekedési útvonalak (,térszerkezeti vonalak") osztják fel térszerkezeti egységekre a teret (bár megfontolandó, hogy ezek inkább tengelyek, semmint határvonalak), Erdősi (1998) pedig azt emeli ki, hogy széleskörủen elfogadott, hogy az autópályák, gyorsvasutak kiépülése a térszerkezetre jelentős hatást gyakorolnak. A müszaki elemek mellett a társadalom mozgása, a térpályák is jelen vannak a térszerkezet elemzések esetében; Mészáros (1994) felfogásában ezek, mint térszerkezet-elemek jelennek meg, illetve Győri (1999) szerint a térszerkezeti kapcsolatok összessége rajzolja fel a térszerkezet vázát.

E szemlélet példái kapcsán azt lehet megállapítani, hogy egy lehatárolt földrajzi térszin térszerkezete összeállhat kisebb egységek térszerkezeteinek együtteséböl, de ugyanakkor lehet értelmezni az adott térrészt átfogó, behálózó elemek (településhálózat, úthálózat stb.) együtteseként is. Elöbbi esetben a földrajzi teret és így a térszerkezetet térelemekböl (térszerkezeti egységekből, itt földrajzi térrészekból) öszszeállíthatóként (,egymás mellé és egymásba rakható térszerkezetek”) kell értelmezni. Utóbbi esetében pedig el kell fogadni, hogy a földrajzi tér különböző dimenziók mentén való tagolása révén külön entitásokat kapunk (például településhálózat, kistáj-beosztás), és ezek (egységeinek térszerkezetei) összekapcsolódása és a felosztások „egymásra rakása” jelenti a területegység térszerkezetét. A szemlélet attól függ, hogy éppen melyik térszerkezeti elemen és vizsgálatán van a hangsúly.

A másik jellegzetes szemlélet a térszerkezet kapcsán a regionalista, amely a térségek, mint térszerkezeti elemek közötti mennyiségi és minöségi differenciákhoz kötödik. A különböző térszerkezeti vizsgálatok alapegységei általában adminisztratív térségek, mivel determináló tényezó a rendelkezésre álló területi adatbázis, vagy akár a területpolitika hivatalos hatóköre, illetve a közigazgatási fennhatóság. E térségek különböző mennyiségi és minőségi adatainak differenciáltsága révén elóálló területi egyenlőtlenségekhez kapcsolható a térszerkezet, úgy mint az adott jellemzö szerinti területi differenciálódás, legföképp az azonos, illetve különböző jellemzőjü térségek egymáshoz való viszonyára (zonális elrendeződés, centrum-periféria stb.) téve a hangsúlyt. (A települési szint és adatokkal feltöltött egységeinek összevetése is megjelenhet, de 
ennek kapcsán ritkábban fogalmazódik meg a térszerkezet, mivel az átfogó területi képen van a hangsúly, amihez a települési szint már tủl aprólékos, mozaikos.)

Az ilyen jellegủ, azaz területi statisztikai adatokra épülö, különböző térségekre készült vizsgálatokra számos hazai eset hozható példaként. Ezeknél a területi egységeket típusokba (kategóriákba) sorolják, s így áll elő az ország, a megye stb. térszerkezete. Például Rechnitzer $(1998,171)$ így különböztet meg Magyarországon több (megyékböl álló) ,a térszerkezetben ... jól elhatárolható csoportot”. Tipikus esetek vehetők a KSH (például Faluvégi [1995]: „Kistérségi vonzáskörzetek. A regionális térszerkezet jellemzői az átmenet éveiben.") vagy a VÁTI által készített anyagokból (például a területfejlesztési országgyúlési beszámolók). BereyKulcsár $(2000,7)$ szerint „,a területi folyamatok értékelésének legfontosabb és legszembetủnőbb eszköze az eltérő társadalmi-gazdasági fejlettségú és fejlödési pályán mozgó térségtípusok alkotta térszerkezet." E munkákban rálelünk (szövegben, ábracímnél) a területi egyenlőtlenségi vizsgálatokból előálló és leírható térszerkezet fogalmára. A lényeges kérdés e szemléletnél, hogy vajon mi a különbség egy jelenség területi egyenlötlensége és térszerkezete között?

A területi egyenlötlenség és térszerkezet fogalma eltérö tartalmú, de úgy tünik, számos esetben beszélhetünk a két fogalom „határterületéről”, mivel a kettő nem válik el élesen, és emiatt gyakorta egymás szinonimájaként jelennek meg a különböző munkákban. Ez valószínúleg nem helyes. Nemes Nagy (1998) azt mondja, hogy a tér és időbeli lét nemcsak egyenlótlenséget, hanem rendezettséget (akár rendezetlenséget) is jelent, és az egyenlőtlenség és rendezettség jellemzői egy alakzatot határoznak meg. Véleménye szerint a regionális tudomány éppen a térbeli alakzatok, eloszlások rendezettségének vizsgálatával léphet túl a területi egyenlőtlenségi vizsgálatokon. (A rendezettség vizsgálata [pl. a területi autokorreláció, a legközelebbi szomszédanalízis módszerével] azonban kevésbé elterjedt a hazai szakirodalomban.) Ha e véleményt osztjuk, akkor azt mondhatjuk, hogy a két jellemzö, az egyenlötlenség és a rendezettség együttes vizsgálata jelentené igazából a regionalista szemléletü térszerkezet-vizsgálatokat. (Emiatt kell fenntartásokkal élni egy statisztikai mutató [pl. GDP/fó] szerinti tematikus térképnél a térszerkezet fogalmának címbeli használatával szemben [,,Az ország fejlettségi térszerkezete”]; a térkép tipikusan területi egyenlőtlenséget mutat.)

$\mathrm{Az}$ itt tárgyalt kétféle térszerkezet szemlélet azonban nem mindig válik szét. Magyarország esetében például a föváros-vidék, nyugat-kelet ellentét, illetve a különbözö térségtípusok (például nyertesek, nekilendülők, stagnálók, vesztesek), valamint a településhierarchia változásai, a különbözö pozíciójú (nyertes, vesztes stb.) települések stb. gyakorta együttesen (vagy különböző kombinációkban) kerülnek leirásra; ilyen átfogó szemléletủ munkák például Horváth 1995; Enyedi 1996; Faluvégi 1996; Nemes Nagy 1997; Beluszky-Györi 1999 stb. Az egyes térkereteket (s így a térszerkezetet) valójában a kutatók választják szét, mivel azok vizsgálata eltérő módszereket kíván (Enyedi 2001), de átfogó kép megrajzolásakor a különböző eredmények (gyakorta) együtt kerülnek bemutatásra. 


\section{A térszerkezet a hazai területpolitikában}

A térszerkezet értelmezésének összetett szemlélete azonban - sajnos - nem jellemző a hazai területpolitikára: ahogyan e tevékenység két része, a területrendezés és a területfejlesztés elszakadt egymástól, úgy fogalomértelmezéseik is részben eltávolodtak, s így a két fentebb ismertetett térszerkezet-felfogás külön jelenik meg. Ráadásul e téren is tapasztalható, hogy a térszerkezet és a területi szerkezet fogalmak egymáshoz való viszonya nem teljesen tiszta. Ezek igazolására számba vehetjük a fogalomértelmezéseiket és fogalomhasználatukat.

Az érvényben lévö 18/1998. KTM rendelet a területrendezés kapcsán az alábbi meghatározást adja: „a) Térségi szerkezeti terv - A térségi infrastruktúra, a térségi területfelhasználás és a településrendszer térbeli rendjét és összefüggéseit ábrázoló terv. A térségi szerkezeti tervben az alapvetö rendeltetés szerint jellemző területhasználat szempontjából térségi területfelhasználási egységek különböztethetök meg." A térségi szerkezet a szakmai nyelvben a térszerkezet: „A térszerkezet fó összetevői az infrastruktúra-hálózat, a területfelhasználás és a településrendszer. Ezek együtteséböl formálódik az urbanizációs és az ökológiai térszerkezet." (VATII 1998, 7) Ez alapján például az Országos Területrendezési Terv konzekvensen használja a kifejezést. A területrendezés terén a területi szerkezet fogalmát illetően azt feltételezhetjük, hogy egyszer úgy tủnik, mintha nem válna el tartalmában a térszerkezettől, például: „Területszerkezet: Másképp térszerkezet.” [Területrendezési fogalmak és értelmezések, 1985]), máskor pedig mintha tartalmi különbséget tennének, például a korábbi Baráth idézet $(1987,36)$ vagy az Országos Területrendezési Terv Koncepciója (4078/79): az ország funkcionális területi szerkezete a múszakifizikai területi szerkezettel együtt alkotja az ország komplex térszerkezetét.

A területfejlesztés szorosan összefonódik a területi kutatásokkal, így ezek kérdései, problémái megjelennek a gyakorlati életben is. A térszerkezet itt is egy központi, ám igazából nem tisztázott fogalom. Ennek kapcsán elsőként egy idézetet citálhatunk a területfejlesztés céljait, kereteit stb. meghatározó, érvényben lévő törvényböl (1996. évi XXI. tv.): ,2. § A területfejlesztés és területrendezés célja: ... c) Az ország térszerkezete, településrendszere harmonikus fejlödésének elösegitése." (A 2004. évi módositás után még bekerült: „21/A. § (1) ... a gazdaság arányosabb térszerkezetének kialakítása, ...”). A törvény szövege alapján „hivatalos szinten elismert” fogalomról van szó. Azonban itt nem lelünk rá a kifejezés értelmezésére, szemben több más hasonló fogalommal (például régió, kiemelt térség, városkörnyék, kistérség, sőt térség). E hiány megmaradt a 35/1998. Országgyủlési Határozat az Országos Területfejlesztési Koncepcióról címủ szövegben is (ahol az alábbi kontextusokban találkozunk például a fogalommal: „térszerkezet felé törekvés”; ,a társadalmi, gazdasági és környezeti céloknak megfelelö térbeli szerkezet kialakítása”; ,a túlzottan Budapest központú térszerkezet oldása"). A kapcsolódó első Országos Területfejlesztési Koncepcióban, majd még inkább az ezt követő különböző, a hazai területi folyamatokról szóló jelentésekben 
is gyakorta használják a térszerkezet fogalmát, méghozzá elég következetesen: legszembetünőbb a komplex mutatók kistérségi egyenlötlenségein alapuló ún. társadalmi és gazdasági térszerkezet térképi bemutatása, valamint elemzése. Mindezt úgy, hogy nincs meghatározva a fogalom tartalma. Azonban a használat egyértelmủen utal arra, hogy a területfejlesztés a térszerkezet regionalista szemléletú értelmezését vallja magáénak. A területi szerkezet kifejezés viszont háttérbe szorult a térszerkezet mögött, bár egyes dokumentumokban még fel-felbukkan.

Azaz adott két országos hatáskörü, hivatalos területpolitikai tervdokumentum, az Országos Területrendezési Terv és az (elsö) Országos Területfejlesztési Koncepció, amelyek eltérö szemléletben használják a fogalmat, más a két mü (és alkotói) térszerkezet-felfogása. Ez a korábbi gondolatmenet alapján persze már nem meglepő, de kérdés, hogy megengedhetö-e? Valószínüleg nem, hiszen nem két diszjunkt szakterületről van szó, a gyakorlatban sok szállal kötődnek egymáshoz (még a törvény is összefüzi öket...). Azonban a területpolitika e két része mintha elszakadt volna egymástól (bár a közös tervezés nem lenne egyedi eset, például létezik a nemzetközi gyakorlatban az ún. Struktúraterv(ezés): a fejlesztési és rendezési tervezés között összekötö kapcsot képezö tervdokumentum; a fizikai tervezést összekötni a társadalmi, gazdasági folyamatok tervezésével [Fogarasi-Orosz 2002]), s e különválás a fogalomértelmezések terén is megjelenik.

Ezen utóbbi helyzeten változtatott valamelyest a 2005-ben elfogadott második Országos Területfejlesztési Koncepció, amely túllépett elődje hiányosságán, mivel a mủ végén gazdag fogalomtár lelhető fel, benne a térszerkezet - több kutató álláspontjával egyező - meghatározásával: „Térszerkezet, területi struktúra: a térbeli objektumok és a közöttük lévő kapcsolatok, viszonyok alkotta, müködőképes rendszer, összetett térkategória, melynek értelmezését és leírását erősen determinálja a közelítés módja, szemlélete. A regionális kutatásokban leggyakrabban a térségek lehatárolt térrészekre bontásával, s általában egy-egy kiemelt jellemzö szerinti értékelésével, térképezésével feltáruló („regionális”) egyenlőtlenségi és rendezettségi sajátosságok összessége." A fogalmi meghatározás nem kizárólagosan területfejlesztési-regionalista szemléletü, mivel a leírás utal a másik szemléletre is, s így kísérlet a két fogalomhasználat közelítésére, vagy legalábbis a kétféle szemléletre való figyelemfelhívásként értelmezhetö. Emellett fontos elem, hogy szinonimák lettek a térszerkezet és a területi szerkezet, mert bár célszerü lenne szétválasztani a kifejezéseket: míg előbbi a területfejlesztés fogalma lehetne (egy regionalista szemléletủ meghatározással), addig utóbbi a területrendezésé (egy műszaki-területtervezési szemléletú definícióval), ennek azonban ellentmond, hogy a területrendezésben és a területfejlesztésben is mindkét fogalom szakterületi értelmezésú tartalommal felruházott használata tetten érhetö, azaz a „szokásjog” itt is él. Amíg azonban ez így marad, addig egymás térszemléletének ismeretében lesz csak hatékony kommunikáció a két szakterület között. 


\section{Összegzés}

A tanulmány összegzéseként elsőként az a trivialitás emelhető ki, hogy nem egyszerü meghatározni a térszerkezet fogalmát. Ha regionális tudományi leírást kell alkotni, akkor a térelemek egyenlőtlensége és rendezettsége együttesen fogható fel térszerkezetként, de véleményünk szerint a térbeli elrendezỏdésre kell inkább a hangsúlyt helyezni. Így - az elrendeződés, rendezettség kiemelésével - lehet ugyanis ellépni a tér legáltalánosabb tartalma (egyenlőtlenség és rendezettség) felöl a térszerkezet felé. Lényeges megállapítás talán az is, hogy a társadalmi térszerkezetet a társadalom külső és belső térszerkezete együtt alkotják; így a külsö, a földrajzi térben célszerübb lenne a földrajzi térszerkezet vagy a területi szerkezet fogalmának a használata. Ezen túl megállapíthatjuk, hogy a földrajzi térszerkezet egy összetett térkategória, s értelmezését, leírását erősen determinálja a közelítés módja, szemlélete. Alapvetően kétféle térszerkezet-felfogás a meghatározó a hazai körökben: a) a földrajzi környezetben a különböző térelemek, térrészek és ezek kapcsolata, kapcsolódása, valamint egymáshoz viszonyított elhelyezkedése, elrendeződése a térszerkezet; b) a különbözô térrészek (leginkább régiók, országok) mennyiségi és minôségi jellemzőinek differenciáltságából eredő területi egyenlőtlenségek és ezek rajzolatai jelentik a térszerkezetet.

\section{Irodalom}

Ashworth, G.-Bora Gy. (1999) Fogalmi meghatározások: vállalat, tér, szervezet. - Ashworth, G.-Bora Gy. (szerk.) Térbeli elrendezés és a vállalat I. Budapesti Közgazdaságtudományi Egyetem Gazdaságföldrajz Tanszék, Budapest. 9-51. o.

Baráth E. (1987) Egy térszerkezeti modell. - Tér és Társadalom. 2. 23-44. o.

Bartke I. (1989) A társadalom és a gazdaság területi szerkezetének alapvonásai. Akadémiai Kiadó, Budapest.

Bartke I. (2001) A területi egyensúlyok. - Tér és Társadalom. 1. 25-38. o.

Bartke I. (2006) Birálat Szabó Pál: „Régió és térszerkezet az Európai Unióban” c. (egyetemi, PhD) doktori értekezéséról. Budapest. Kézirat.

Benedek J. (2000) A társadalom térbelisége és térszervezése. Risoprint, Kolozsvár.

Benko, G. (1999) Regionális tudomány. Dialóg Campus Kiadó, Budapest-Pécs.

Berey K.-Kulcsár G. (2000) A területfejlesztési országgyűlési beszámoló összefoglaló ismertetése. Falu-Város-Régió. 9.9-12. o.

Biológiai Lexikon. (1978). 4. kötet Akadémiai Kiadó, Budapest.

Bodó B. (2005) Kistérségek, civilek, szerkezetek. - Tér és Társadalom. 1. 115-141. o.

Beluszky P.-Gyôri R. (1999) A magyarországi városhálózat és az EU-csatlakozás. - Tér és Társadalom. 1-2. 1-30.0.

Beluszky P.-Gyôri R. (2004) Fel is út, le is út... (Városaink településhierarchiában elfoglalt pozícióinak változásai a 20. században) - Tér és Társadalom. 1. 1-41. o.

Böhm A. (1996) A magyar társadalom tagoltsága. - Perczel Gy. (szerk.) Magyarország társadalmigazdasági földrajza. ELTE Eötvös Kiadó, Budapest. 189-222. o.

Czirfusz M. (2007) A struktúrák regionális egyenlőtlenségei. - Tér és Társadalom. 1. 69-84. o.

Dusek T. (2004) A területi elemzések alapjai. Regionális Tudományi Tanulmányok 10. ELTE Regionális Földrajzi Tanszék - MTA-ELTE Regionális Tudományi Kutatócsoport, Budapest.

Enyedi Gy. (1996) Regionális folyamatok Magyarországon. Hilscher Rezsó Szociálpolitikai Egyesület, Budapest.

Enyedi Gy. (2001) Tájak, régiók, települések Magyarországon. - Ezredfordulỏ. 4. 19-23. o.

Enyedi Gy. (2002) A regionális tudomány. MTA RKK ATI jubileumi konferenciája, Kecskemét, Előadás. 
Erdösi F. (1998) A transzeurópai hálózatok hatása a területi fejlődésre. - Tér és Társadalom. 3. 29-54. o.

Faluvégi B. (1995) Kistérségi vonzáskörzetek. A regionális térszerkezet jellemzői az átmenet éveiben. KSH, Budapest.

Faluvégi A. (1996) A regionális térszerkezet változásának jellemzői. - Comitatus. 4. 3-15. o.

Faragó L. (2004) A regionalizmus hajtóerői Magyarországon. - Térés Társadalom. 3. 1-23. 0.

Faragó L. (2005) A jövőalkotás társadalomtechnikája. Dialóg Campus Kiadó, Budapest-Pécs.

Fodor L. (1985) A társadalmi tér elméleti kérdései a térelmélettel foglalkozó tudományok megállapításainak tükrében. Kandidátusi értekezés tézisei. Budapest.

Fogarasi Gy.-Orosz Gy. (2002) Struktúraterv, avagy egy hazánkban új tervezési múfaj a Középmagyarországi régióban. - Falu-Város-Régió. 1. 20-23. o.

Frisnyák S. (1996) Magyarország kultúrgeográfiai korszakai (895-1920). - Tér és Társadalom. 1. 39-49. o.

Golobics P. (2002) A világgazdaság kialakulásának folyamata és jelenlegi térszerkezete. - Tóth J. (szerk.) Altalános társadalomföldrajz I. Dialóg Campus Kiadó, Budapest--Pécs. 25-82. o.

Győri R. (1999) Térszerkezeti változások a polgárosodó Kisalföldön. - Tér és Társadalom. 4. 77-106. o. Horváth Gy. (1995) A magyar regionális politika erös és gyenge pontjai. - Comitatus. 7. 3-10. o.

Horváth Gy. (1989) A regionális gazdaságszervezés fejlödése és intézményei. Területi és települési kutatások 4. Akadémiai Kiadó, Budapest.

Horváth Gy. (1999) Elószó a magyar kiadáshoz. - Benko, G. Regionális tudomány. Dialóg Campus Kiadó, Budapest-Pécs. 9-13. o.

Jakobi Á. (2004) Az információs társadalom területi egyenlôtlenségeinek tartalma és értelmezési lehetōségei. Elöadás. II. Magyar Földrajzi Konferencia, Szeged. http://geography.hu/mfk2004

Köszegfalvi Gy. (1985) A magyarországi településrendszer strukturális változása. - Rechnitzer J. (szerk.) Vonzáskörzetek - agglomerációk II. Akadémiai Kiadó, Budapest. 31-54. o.

Kocsis Zs. (1996) A települések belső szerkezetének vizsgálata a lakosság térbeli eloszlása alapján. - Tér és Társadalom. 2-3. 133-140. o.

Korompai A. (1995) Regionális stratégiák jövőkutatási megalapozása. Regionális Tudományi tanulmányok 1. ELTE Regionális Földrajzi Tanszék, Budapest.

Krajkó Gy. (1989) A gazdasági térszerkezetek és a közigazgatás összefüggései. - Tér és Társadalom. 3. 53-69. o.

Magyar Értelmezó Kéziszótár (1972) Akadémiai Kiadó, Budapest.

Mészáros R. (1994) A település térbelisége. JATEPress, Szeged.

Mészáros R. (2000) A társadalomföldrajz gondolatvilága. SZTE, Szeged.

Nemes Nagy J. (1997) Régiók, regionalizmus. - Educatio. 3. 407-423. o.

Nemes Nagy J. (1998) A tér a társadalomkutatásban. Bevezetés a regionális tudományba. Hilscher Rezső Szociálpolitikai Egyesület, Budapest.

Nemes Nagy J. (2003) A regionális tudomány dualitása és paradigmái - hazai tükörben. - Tér és Társadalom. 1. 1-17. o.

Paksy G. (1997) Hét kérdés a területrendezésröl. - Falu-Vảros-Régió. 5. II-VIII. o.

Patik R. (2005) A regionális klaszterek feltérképezéséről. - Területi Statisztika. 6. 519-541. o.

Probáld F. (1995) A regionális földrajz helye a geográfiảban. Regionális Tudományi Tanulmányok 2.

ELTE Regionális Földrajzi Tanszék, Budapest. 35-63. o.

Rechnitzer J. (1998) Területi stratégiák. Dialóg Campus Kiadó, Budapest-Pécs.

Rechnitzer J. (1999) Az állami vagyon magánosításának területi dimenziói. - Tér és Társadalom. 3. 101-120. o.

Strassoldo, R. (1990) The Social Construction and Sociological Analysis of Space. - Hamm, B.-Jalowiecki, B. (eds.) The social nature of space. Panstwowe Wydawnictvwo Naukove, Warszawa. 19-47. o.

Süli Zakar I. (1997) Régiók a földrajzi térben. - Comitatus. 3-4. 7-16. o.

Szabó P. (2005) Régió: „meghatározott területi egység”. Regionális Tudományi Tanulmányok XII. ELTE Regionális Földrajzi Tanszék-MTA-ELTE Regionális Tudományi Kutatócsoport, 7-61. 0. [http://geogr.elte.hu/REF/REF_hirek_anyagok.htm]

Tóth J. (1993a) A városokra épülō középszint lehetősége. - Európába megy-e a megye? Konferenciakötet. Baranya Megyei Közgyülés, Pécs. 119-124. o.

Tóth J. (1993b) Nagyvárosok a magyar településrendszerben. - Comitatus. 7-8. 40-53. o.

Tóth J. (1996) Régiók Magyarországon. - Perczel Gy. (szerk.) Magyarország társadalmi-gazdasági foldrajza. ELTE Eötvös Kiadó, Budapest. 587-645. o.

Tóth J.-Pap N. (2002) Rajon- és régióelméletek. - Tóth J. (szerk.) Altalános társadalomföldrajz II. Dialóg Campus Kiadó, Budapest-Pécs. 289-304. o.

Varga A. (2005) Agglomeráció, technológiai haladás és gazdasági növekedés: a $K+F$ térszerkezet makrogazdasági hatásainak vizsgálata. Akadémia Doktora Értekezés, Pécs. 
VÁTI Kht. (1998) A Készülö Országos Területrendezési Tervtöl. - Falu-Város-Régió. 5. 3-15. o. Villányi A. (1995) Kémia - összefoglaló középiskolásoknak. Múszaki Könyvkiadó, Budapest. Zoltán Z. (1984) A dinamikus gazdaságföldrajz elmélete. Tankönyvkiadó, Budapest.

\section{THE CONCEPT AND THE EXPLANATION OF THE SPATIAL STRUCTURE}

\section{PÁL SZABÓ}

The aim of this paper is to describe and construe one main notion of geography, regional economy and regional science: the spatial structure. The research is based on the elaboration of numerous Hungarian studies (books, articles) which use this notion. The use of the notion in different areas of social science was analysed and its different types were described in this paper. In regional science and geography there are a couple of different definitions of the spatial structure and they were categorized as well. Finally we tried to describe the extension of this notion in regional science. 